\section{NFC technology acceptance for mobile payments: A Brazilian Perspective}

\author{
Iviane Ramos de Luna \\ CAPES Foundation - Ministry of Education of Brazil and University of Granada, \\ Marketing and market research department, Granada - Spain \\ Francisco Montoro-Ríos \\ Francisco Liébana-Cabanillas \\ University of Granada, Marketing and market \\ research department, Granada-Spain \\ Joáo Gil de Luna \\ State University of Paraiba, Statistics department, Campina Grande - Brazil
}

Received on

$01 / 11 / 2015$

Approved on

08/30/2016

\section{Responsible editor:}

Prof. Dr. Guilherme de Farias

Shiraishi

\section{Evaluation process:}

Double Blind Review

\begin{abstract}
Purpose - This study investigates the acceptance of NFC technology for payment through mobile in a Brazilian context, which allow knowing the factors that influence directly or indirectly in that acceptance.

Design/methodology/approach - Through an online and selfadministered questionnaire and using the snowball sampling procedure on social networks, the final sample consisted of 423 mobile phone users in Brazil and the technique used to prove the hypotheses was the Structural Equation Model.

Findings - The results show that attitude, personal innovation in IT and perceived usefulness are determinants of future intention to use the NFC technology for payments in Brazil.

Originality/value - The proposed model has a predictive power of intention to use NFC payment of $71 \%$, demonstrating that it includes background with a large predictive power of acceptance of NFC technology which led us to highlight the main implications for the management and development of new studies in this field.
\end{abstract}

Keywords - Mobile payments, NFC, TAM, new technologies acceptance.

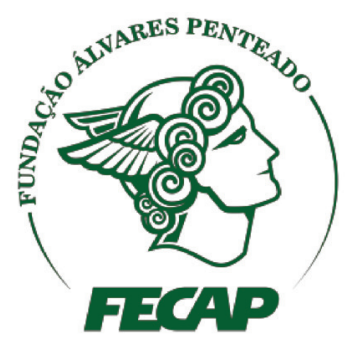

\section{Review of Business Management}

DOI: $10.7819 /$ rbgn. v0i0.2315 


\section{Introduction}

To enhance the process of adoption and use of mobile payment services, it is important for both businesses and consumers to deepen their knowledge of these services. Based on this idea, the present study aims to investigate the acceptance of NFC (Near Field Communication) technology for mobile payments in Brazil so as to determine the factors that directly or indirectly influence its acceptance. After extensive research on the subject and experiencing the reality of mobile payments, we realized that there are no specific studies on NFC's acceptance in Brazil. It is for this reason that this study is relevant both for Brazilian academia and the mobile industry.

It is obvious that mobile phone adoption is rapidly growing in Brazil as it is throughout the world. The many features included in these devices that help make daily life easier, more enjoyable and fun explain their widespread use (Luna, Montoro-Ríos, \& Liébana-Cabanillas, 2016). There are now 7.4 billion mobile subscriptions worldwide and between 2015 and 2021. The IoT (Internet of Things) indicates a further increase in smartphone adoption that will reach 16 billion. This suggests that by 2018 smartphones will be the largest category of electronic connected devices (Ericsson, 2016).

Brazil is among the five countries in the world with the highest number of mobile phones. The others are China, India, Indonesia and the USA (Central Intelligence Agency [CIA], 2016). Brazil's mobile market potential is evident. It is the largest in Latin America and is the fourth largest in the world according to GSMA Association in its latest edition of the Brazil Mobile Observatory (2012). In fact, Brazil ended the first quarter of 2016 with a total of 257.81 million active mobile telephone lines (Agência Nacional de Telecomunicações [ANATEL], 2016), with about 23 million $4 \mathrm{G}$ mobile connections that by the end of 2016 is expected to reach 42 million, according to data from the GSMA Intelligence (2016).

This growth will be driven by increased penetration of smartphones in the country that will leap from $55 \%$ in 2015 to $62 \%$ by the end of 2016 despite pressure on prices in the macroeconomic environment. With consumers replacing their mobile phones with smartphones and consequently with the move towards faster networks (a significant increase in the new $4 \mathrm{G}$ connections is expected), it is assumed that total 3G and 4G mobile connections will reach 223 million by the end of 2016. This represents a growth of nearly $16 \%$ compared to 2015 (GSMA Intelligence, 2016).

Specifically, in Brazil smartphones have played an important role in the development of the market and have had a deep impact on consumer behavior. Of the total smartphones users, $80 \%$ have searched for a product or service of interest, $41 \%$ have recommended or reviewed the company to others, and 55\% have made purchases from an online or physical store (Google, 2012). The scenario indicates that the smartphone market is huge, global and strategically important to all interested in monetizing digital content and distribution services and mobile marketing programs. In this sense, the scenario is favorable to mobile payments as it eliminates use of the physical wallet, replacing it with a single device, the smartphone.

Mobile payments allow consumers to eliminate or reduce the need of cash (Pham \& Ho, 2015), offering convenience and speed (Teo, Tan, Ooi, Hew, \& Yew, 2015), performance and secure transfer of information from the simple transaction to situations with high volume of payments such as restaurants or large retailers (Leong, Hew, Tan, \& Ooi, 2013). Both business and consumers benefit from a considerable reduction in operating time, thus achieving clear benefits in productivity (Oliveira, Thomas, Baptista, \& Campos, 2016), adding value to small and medium-sized businesses. For these reasons mobile payments have a large growth potential. Moreover, according to the survey conducted by the Statista Corporation (2015), the global mobile payment revenues are expected to reach 721 billion USD in 2017 making it one of the 
most important means of conducting mobile financial transactions.

In recent years, consumers have used their smartphones as personal digital assistants and shopping devices. In the US, $79 \%$ of smartphone users are also mobile consumers, most often though by means of specific retail applications in stores such as Best Buy, Kohl or Macy's. Through mobile applications, the shopper can check prices, discounts, additional information and reviews of products, compare product features, and ask opinions from friends (Kang, Mun, \& Johnson, 2015; Kerviler, Demoulin, \& Zidda, 2016).

On the other hand, smartphone manufacturers such as Apple, Samsung and Google have recently launched mobile payment services (Apple Pay, Samsung Pay and Android Pay) raising the awareness of customers about the options of m-payment (Kerviler et al., 2016). However, only half of the users actually buy with these devices (Emarketer, 2015) and only about $15 \%$ use m-payment regularly (First Annapolis, 2016). In this sense, mobile shopping seems to have a greater impact on traditional sales (in physical stores) than on mobile commerce sales (Groß, 2015; Kerviler et al., 2016).

The latest study by Accenture (2015) shows that consumers see themselves using less traditional means of payment and turning to digital payment in the future, in spite of the fact that it is not commonly used today. By the end of that decade, Accenture expects a significant increase in m-payments. However, entities involved in the commercialization of mobile payments still need to dedicate more effort to understand the consumer and how to manage the increase in an enduring way.

Currently, the development of applications and new business models related to $\mathrm{m}$-commerce (mobile commerce) such as mobile payments is in full growth. There are many solutions in the market using different means and technologies. NFC technology, also called contactless payment, is a common factor among them. Payment methods developed by three of the world's major mobile technology industries (Apple Pay, Samsung Pay and Android Pay) are examples. Similarly, startups are also investing in this technology despite little success coupled with criticism as in the case of the Google Wallet app launched in 2011.

NFC technology has become one of the most promising technologies in recent years due to the business opportunities in its application for mobile phones and reliance on important features in the short term beyond the mobile payment (Luna et al., 2015). NFC could present traders with the means for its consumers to communicate directly with companies through products, applications or mobile payments. For example, when examining a NFC chip in a package, the client could send real-time information directly to the manufacturer, generating extremely valuable information since the technology allows discerning both what is happening with their products after they have leave the shelves and the buying habits of their customers (Simpson, 2015). It is for these reasons that we chose to study this technology.

Mobile payments in Brazil are still in the embryonic stage. This is understandable since the ecosystem of mobile payments requires the creation of accords between various players. It is essential to develop an interest and synergy between banks, technology businesses, credit card companies, telephone services, startups, governments, businesses, customers and other stakeholders.

Payment with mobiles is a relatively new area of research, compared to other similar subjects such as online trading, Internet banking or mobile banking. Some authors consider that this is a subject that is in its infancy (Slade, Williams, \& Dwivedi, 2013), in spite of the significant advances in recent years in this field (Dahlberg, Guo \& Ondrus, 2015) Furthermore, many experts consider mobile payment as having the greatest potential in this sector ((Liébana-Cabanilla, Ramos-De-Luna, \& Montoro-Ríos, 2015). Only a few studies on the subject have appeared in recent leading academic journals (Slade, Williams, 
Dwivedi \& Piercy, 2014; Luna et al., 2016, Oliveira et al., 2016). Yet they coincide on the need to develop a better understanding of the factors that determine mobile payment adoption.

The need to study mobile payments in Brazil has been noted in other research (Bourreau $\&$ Verdier, 2010) that compares the number of credit/debit cards with the number of mobile phones in developed and developing countries. The results reveal a larger amount of credit/debit cards than mobile phones in developed countries and the opposite in less developed countries. This therefore presents an interesting opportunity to promote mobile payment as an electronic payment solution to a population that does not benefit from banking services. In addition, access to, and use of new technologies is seen as essential in today's society because of the potential it offers to the world economy described as being based on directed knowledge and information (Duncombe \& Boateng, 2009).

To achieve this goal, we carried out, in section 2, a clarification of the technical concepts related to the technology. This is followed, in section 3, by a review of the main theories of acceptance/adoption of technological innovations and mobile payments, and a proposal of a model based on the theoretical review that attempts to explain by enunciating different hypotheses the process of acceptance of NFC technology. Section 4 presents the methodology, including the measurement instrument, the techniques to analyze the data and the sample profile. Section 5, by means of a structural equation model, estimates the adequacy of the theoretical model to explain the relationships between the different factors that, from the user point of view, influence the acceptance of NFC payment. Finally, section 6 lays out the findings of the study, including its limitations and advances future lines of research.

\section{What is near field communication (NFC) technology?}

NFC technology is a type of contactless technology that enables an instantaneous transmission of data by simply approaching a device in a distance of less than $4 \mathrm{~cm}$ to a receiver (e.g. mobile phone). The potential of this type of contactless technology to improve commercial processes such as the speed of purchase, immediate product information, interactive ads, and the possibility of companies to perceive the shopping habits, etc., allows the technology to be considered an attractive tool for companies, customers, as well as for research.

One of the central elements of NFC mobile services is the question of security (ES), "a secure microprocessor (a smart card chip) that includes a cryptographic processor to facilitate transaction authentication and security, and provides secure memory for storing payment applications (e.g., American Express, Discover, MasterCard, Visa and other payment applications). SEs can also support other types of secure transactions, such as transit payment and ticketing, building access, or secure identification" (Madureira, 2017, p.133; Smart Card Alliance, 2011).

Although the NFC technology was developed in 2004, it still is going through experimental tests of acceptance by users nowadays. A number of projects designed for mobile payments using contactless technology have been carried out around the world, with Europe as one of the leaders. Over the years the technology has been subject to a number of improvements; especially after the creation of the NFC Forum. The first NFC payment service, Google Wallet, was launched in the United States towards the end of 2011. The same year, PayPal, a company of digital payments, sued Google for trade secrets theft, which resulted in a loss of credibility for Google. Nevertheless, the Google Wallet application registered 36,500 downloads by June 2016 .

Since 2011, when the first payment service market was launched, NFC technology has gone through major changes to adapt to new environments and features, and repair the glitches in safety and performance (Brada \& Brada, 2016). The scenario in which the technology operates 
also evolved allowing it to assume its place in the field granting consumers knowledge of its existence and its ease of use. NFC technology has been considered by certain authors as the future of mobile payment services (Ondrus \& Pigneur, 2007; Luna et al., 2016; Morosan \& Defranco, 2016). This is bolstered by the dramatic development in recent years of m-payment technology following the emergence and spread of a new set of mobile and smart devices that include a large number equipped with NFC technology (Oliveira et al., 2016).

In Brazil, $85 \%$ of points of sale devices (POS) are currently capable of receiving payment by means of devices equipped with NFC technology such as Apple Pay to be released in late 2016. Samsung Pay and Android Pay, its competitors, are also introducing the technology. Sciarrettta (2016), in the latest issue of Ciab FEBRABAN magazine, notes that the latter two mobile payment systems are considered more user-friendly by financial institutions because they do not rely on the latest types of devices or apply charges for transactions. Banking institutions such as the Bank of Brazil, Caixa, Itaú, Bradesco, HSBC, Santander and Porto Seguro have announced a partnership with Samsung Pay in Brazil. Banks are also dealing with Apple Pay to bring the service to the country but have not specified the status of the negotiations. Moreover, a popularization of mobile payments in the coming months is expected as consumers replace current mobile phones with newer smartphones (Sciarretta, 2016).

What is perceived is a scenario of mass development of mobile payments. Although this still depends on several factors the main factor at this stage is the acceptance of end-users (consumers and businesses). The advances are continuous and the parties interested in the development of this type of payment still seek ways to optimize the service in order to generate an increasingly effective model for financial transactions. Financial institutions are also constantly seeking to promote an online payment security leap in quality while technology companies are constantly exploring ways to develop an easier and faster use of this technology.

These facts reveal that although many consider that NFC's arrival is for the long-term, it is in fact now very real and close. This view of the future of payments shows the need for businesses, consumers, banks and other stakeholders to study mobile contactless payments and the factors that may influence the adoption of this new means of purchasing goods and services.

\section{Literature review}

The current work reviewed several studies regarding the adoption of information technology (IT), especially those related to adoption of mobile payments services and mobile technological innovations. Most of the research in these fields is based on use or future use of existing technologies. Yet NFC, the object of this study, despite being a mature technology, is not in use in Brazil. Taking this into consideration, the current study develops a model to measure the intention of future use based on existing literature.

The model starts from the assumption that the Technology Acceptance Model (TAM) designed by Davis (1989) provides a good base to explain the use of m-payments (Dahlberg, Mallat, \& Oorni, 2003) and that the constructs the TAM are quite general and of universal use for different computer systems and different populations (Malhotra \& Galletta, 1999). Moreover, this theory has been widely accepted and implemented in various investigations on the adoption of different technologies, including mobile technologies (Kim, Mirusmonov, \& Lee, 2010; Lu, Yang, Chau, \& Cao, 2011; Yang, Lu, Gupta, Caso, \& Zhang, 2012). For these reasons, this work is based on the original TAM model by Davis (1989) in spite of not excluding other important factors from both classic models and recently developed models that show a high amount of explained variance of intention to use technology. 
In what refers to classic models, we have included the "subjective norms" of Fishbein and Ajzen (1975) from Theory of Planned Behavior (TPB), the Theory of Reasoned Action (TRA) by Ajzen (1991) and finally the Theory of Acceptance Model 3 (TAM 3) by Venkatesh and Bala (2008) as determinants of attitude and intention to use a technology. We also included the "perceived compatibility" suggested in the Innovation Diffusion Theory (IDT) by Rogers (1983) as a determinant of attitude to the use of technology and predetermining its intended use.

Among the research centered specifically to mobile technologies is the work of Lu, Yao and Ye (2005) (2005) that sought to empirically identify factors driving to the adoption of Wireless Internet Via Mobile Technology (WIMT). This model states that the determining factors in the intention to adopt this type of service are its perceived usefulness and its perceived ease of use. These factors are, in turn, determined by social influences and personal innovation. It was therefore possible through this model to explain $57 \%$ of the explained variance of the intention to adopt the technology.

Schierz, Schilke and Wirtz (2010) also attempted to gain a better understanding of the determinants of acceptance of mobile payment services by consumers and the reasons why the service has not gained widespread use despite the fact that mobile technology has become so common in today's everyday life. The Schierz et al. (2010) model, although based on TAM, includes other variables that influence the attitude and intention to use mobile payments. These authors found a strong empirical support in the questions of compatibility, individual mobility and subjective norms. The Schierz et al. (2010) model was able to explain $84 \%$ of the attitude to use and $85 \%$ of the intention use of mobile payment demonstrating that the model brings together a set of important factors that could be used to explain the intention to adopt other types of mobile payments.

For these reasons the current work includes the three following variables that are equally important to study the acceptance of this technology to pay with mobile phones: a) "perceived security," b) "individual mobility," and c) "personal innovation in information technology". These are included in more recent models with significant explained variances $(\mathrm{Lu}$ et al., 2005; Shin, 2009; Lu et al., 2011; Kim et al., 2010; Yang et al., 2012). From these five constructs, plus the four proposed in the original TAM developed by Davis (1989), we propose a model contrasting 15 hypotheses with the ultimate goal of explaining the intention of the Brazilian population to adopt the NFC mobile payment service.

\section{I Hypotheses}

Following the example of Venkatesh and Davis (2000), we initiate the section of hypotheses with the core of the TAM model followed by additional constructs extending the original theory adapted to NFC technology. The discussion begins with the hypotheses related to the technology itself before presenting factors related to social context, as well as two factors characteristic of users.

An important dependent variable in studies based on the TAM is the intention to use (Van Der Heijden, 2003). This variable is also key in studies on the acceptance of mobile payments (Chen \& Adams, 2005; Kim et al., 2010; Yang et al., 2012). This intention is defined as the probability that an individual will use a technology.

Several studies such as those of Chen and Adams (2005), Meharia (2012) and Schierz et al. (2010) based on the results garnered by Davis (1989) found that the main antecedent and key mediator of influence of the other variables on intention to use is the attitude of a person toward the use of a particular technology. That can be understood as the positive or negative assessment of the use of a technology held by a particular individual.

Since other studies focusing on mobile technologies have identified a positive relationship 
between attitude towards use and intention to use of certain technological innovations (BignéAlcañiz, Ruiz-Mafé, Aldás-Manzano, \& SanzBlas, 2008; Lu, Yu, Liu, \& Yao, 2003), this current study proposes a similar relation for the case of NFC mobile payment:

H1: The attitude towards the use of NFC technology for payment with a mobile phone determines the intention to use this type of payment.

The idea of ease of use refers to an individual's perception that using a particular system will not require effort to carry out a particular task (Davis, 1989). In this case, the perception refers to the ease of making a payment by means of NFC technology. Davis considered the ease of use as one of the attributes with the greatest influence on the adoption of new technologies. This influence is manifested through a double impact: one in the Attitude due to selfefficacy and instrumentality and the other in the usefulness, as in the case of the TAM.

The effect of ease of use over perceived usefulness has been shown in multiple studies applied to different contexts (Liébana-Cabanillas, Muñoz-Leiva, Ibáñez-Zapata, \& Rey-Pino, 2012; Luna, 2012; Muñoz, Hernández-Méndez, \& Sánchez-Fernández, 2012), as well as the relationship between ease of use with attitude (Chau \& Lai, 2003; Hernández, 2010). Based on these arguments, we propose:

H2: The consumer's perceived ease of use of the NFC mobile payment system determines his/her attitude towards using this system.

H3: The consumer's perceived ease of use of the NFC mobile payment system determines his/her perceived usefulness of this means of payment.

The perceived usefulness is a fundamental antecedent to the attitude towards the use of a particular technology (Davis, 1989). Several studies over the years have also proved the importance of this construct for the study of technology acceptance (Chen \& Adams, 2005; Yusta, Ruiz \& Zarco, 2010; Meharia, 2012) which does not allow us to disregard it in the framework of the study of acceptance of NFC technology in payments with mobiles.

According to Rogers' (2003) theory of diffusion, users are only willing to accept the innovations if they offer a unique advantage over existing solutions. Recognizing that the proper perception of the utility of NFC technology to more effectively perform payments is critical to its acceptance, we propose the following hypothesis of this study:

H4: The consumer's perceived usefulness of NFC mobile payment positively determines his/her attitude towards the use of this type of payment system.

Subjective norms, also called social influences, are used in various models of acceptance of technology, as well as in their more recent adaptations (Fishbein \& Ajzen, 1975; Venkatesh \& Bala, 2008). According to Yang et al. (2012), the TRA and the TPB explain that the intention of an individual to adopt an innovation is not only determined by attitude, but also by subjective standards that make up the his/her values of conduct and standards.

This factor is defined as the degree to which an individual considers the opinion of other individuals close to him (family and friends) regarding to the adoption of a system or carrying out a certain action. (Fishbein \& Ajzen, 1975; Venkatesh $\&$ Davis, 2000; Venkatesh \& Bala, 2008).

This social construct consists of two basic sets of underlying factors. First is the opinions that the consumer has of people considered as a reference, and the second is the motivation of the person to behave in accordance with the wishes of the people or reference groups (Herrero Crespo, García de Los Salmones, \& Rodríguez Del Bosque, 2005; Davis, Bagozzi, \& Warshaw, 
1989). From this point of view, many authors identified a direct and positive link between subjective norms and ease of use (Lu et al., 2005; Bhatti, 2007), usefulness (Zhang, Yue, \& Kong, 2011; Venkatesh \& Davis, 2000; Taylor \& Todd, 1995;) and intention of use (Shih \& Fang, 2004; Shin, 2009; Glass \& Li, 2010; Chung, Stoel, Xu \& Ren, 2012;). Accordingly, we propose the following hypotheses:

H5: Subjective norms determine the consumer's intention to use the NFC mobile payment system in the near future.

H6: Subjective norms determine a consumer's perceived usefulness of the NFC mobile payment system.

H7: Subjective norms determine the perception of the ease of use of the NFC mobile payment system by the consumer.

A major concern both for business and consumers is payment security, especially when it comes to new means of purchasing products and services involving novel technology, as was once the case of the credit card and will possibly be the case of NFC.

Grassie (2007) states that safety must be a priority in order for NFC applications to be successfully adopted. When consumers evaluate the use of the consequences of a particular product, they not only evaluate the immediate consequences, but also the internal consequences which can often lead to conclusions of potential benefits or risks of a product (Cho, 2004). This can affect both the intention to use the NFC as well as the perception of its utility. Based on these arguments, we propose the following hypotheses:

H8: $A$ consumer's perceived security of the NFC mobile payment system determines his/ her intention to use it.

H9: A consumer's perceived security of the NFC mobile payment system determines his/ her perceived usefulness of the system.
We can understand the compatibility as well as the degree to which technological innovation is perceived by potential users as consistent with their values, needs and past experiences (Rogers, 1983). This reveals the importance of this factor in this study as it combines technological innovation with values, behavioral patterns and consumer experiences. Tornatzky and Klein (1982) affirm that the compatibility perceived by a user is a fundamental feature leading to the acceptance of a particular technology such as the NFC. Recognizing the importance of this aspect, and considering that it is critical to ascertain the degree of impact of this factor on the acceptance of the NFC system in Brazil, we have therefore included the following hypotheses in our model:

H10: A consumer's perceived compatibility determines his/her attitude towards the use of the NFC mobile payment system.

H11: A consumer's perceived compatibility determines his/her perceived usefulness of the NFC mobile payment system.

Given the great popularity of smartphones in the market, it is common to see people carrying out all sorts of activities with their devices. This leads to the belief that we possibly live in the times of "nomadicity" of computing and communication described by Kleinrock (1997) where a variety of portable devices allow people to be in touch with the world even when they are on the go, without a fixed point to communicate, or perform other activities.

Individual mobility, an idea brought up for the first time in the study of Schierz et al. (2010), is based on this concept of "nomadicity", because it refers to how a particular person desires to remain in contact and maintain activities from anywhere by means of the technology currently offered. This can vary greatly between individuals even with the widespread use of mobile devices. Based on these thoughts and following the results 
of the study of Schierz et al. (2010), we propose the following hypotheses:

H12: The consumer's individual mobility determines the perceived usefulness of the NFC mobile payment system.

H13: The consumer's individual mobility determines the attitude of using the NFC mobile payment system.

H14: The consumer's individual mobility determines the intention to use the NFC mobile payment system in the near future.

Considering that the NFC is an innovative technology for the mobile payment market that will become a worldwide trend in a few years, from the review of specialized literature, we believe it is important to consider the influence of the factor of Personal Innovativeness in Information Technology (PIT) proposed by Agarwal and Prasad (1998) that has also been applied in other studies (Agarwal \& Karahanna, 2000; Thatcher \& Perrewe, 2002; Lewis, Agarwal, \& Sambamurthy, 2003). In light of this trend, it gives prominence to the fact that the perception of the end user can vary according to different characteristics before the adoption of technology.

Agarwal and Prasad (1998) define this factor as the will of an individual to try all any of the information technology, conceived as a trait that is not influenced by environmental or internal variables. For these reasons we consider relevant to determine the effect of this factor on the intention to use the NFC. This has proven effective in the study of Lu et al, (2005), as well as the perceived usefulness and ease of perceived use, as found in Yang et al. (2012). Given these reasons we propose the following hypotheses:

H15: The Personal Innovativeness in Information Technology (PIIT) of the consumer determines the perceived usefulness of the NFC mobile payment system.
H16: The Personal Innovativeness in Information Technology (PIIT) of the consumer determines the perceived ease of use the NFC mobile payment system.

H17: The Personal Innovativeness in Information Technology (PIIT) of the consumer determines the intention to use the NFC mobile payment system in the near future.

\section{Methodology}

In this section we present the details of the methodology applied to the research, the preparation of the measurement instrument, the procedure of collection of data, the characteristics of the sample and the techniques used for data analysis.

\section{I Measurement instrument}

The items chosen in this study are founded on research carried out with the conceptual construction of each variable included in the proposed model in order to ensure the instrument's validity. Most of the items were originally developed in English so, for the needs of the study in Brazil, it was necessary to first translate them into Portuguese. In some cases, the wording was modified to adapt to the Brazilian context of the mobile payment NFC systems. Table 1 provides a list of the items and their references.

The self-administered questionnaire, available online, was subject to a series of preliminary tests. The link was available online between January 1 and April 10, 2013. It comprised 34 statements along with a seven-point Likert scale of responses with 1 corresponding to "strongly disagree" and 7 to "strongly agree". The questionnaire also included a filter question to detect the level of knowledge of NFC in Brazil since the technology is new. Individuals who responded (1) do not know it; (2) heard of, but do not know it or how it works; (3) heard of, mostly from the media; and (5) do not know/did not respond, were invited to view a video explaining the NFC payment system by mobile phone. 
Tabela 1

Itens do instrumento de medida

\begin{tabular}{|c|c|c|c|}
\hline Construct & Items & & Authors \\
\hline \multirow{4}{*}{$\begin{array}{l}\text { Attitude toward the } \\
\text { use of NFC payment } \\
\text { systems }\end{array}$} & ATU1 & The use of NFC mobile payment is a good idea & \multirow{4}{*}{$\begin{array}{l}\text { Oh et al. (2003), } \\
\text { van der Heijden (2003), } \\
\text { Yang and Yoo (2004), } \\
\text { Schierz et al. (2010) }\end{array}$} \\
\hline & ATU2 & The use of NFC mobile payment is convenient & \\
\hline & ATU3 & The use of NFC mobile payment is beneficial & \\
\hline & ATU4 & The use of NFC mobile payment is interesting & \\
\hline \multirow{4}{*}{$\begin{array}{l}\text { Intention to use NFC } \\
\text { payments systems }\end{array}$} & IU1 & Given the opportunity, I will use a mobile NFC payment system & \multirow{4}{*}{$\begin{array}{l}\text { Davis (1989), Gefen et } \\
\text { al. (2003), } \\
\text { Venkatesh and Davis } \\
\text { (2000), Schierz et al. } \\
(2010)\end{array}$} \\
\hline & IU2 & I am likely to use a NFC payment system in the near future & \\
\hline & IU3 & I am open to using NFC mobile payment system in the near future & \\
\hline & IU4 & $\begin{array}{l}\text { I intend to use an NFC mobile payment system when the opportunity } \\
\text { arises }\end{array}$ & \\
\hline \multirow{4}{*}{$\begin{array}{l}\text { Perceived usefulness of } \\
\text { NFC payment systems }\end{array}$} & PU1 & NFC mobile payment system is useful mode of payment & \multirow{4}{*}{$\begin{array}{l}\text { Bhattacherjee (2001), } \\
\text { Devaraj et al. (2002), } \\
\text { van } \\
\text { der Heijden (2003), } \\
\text { Schierz et al. (2010) }\end{array}$} \\
\hline & PU2 & Using NFC mobile payment makes the handling of payments easier & \\
\hline & PU3 & $\begin{array}{l}\text { NFC mobile payment system allows quick use of mobile applications } \\
\text { (for example, ticket purchases, and use of mobile coupons, etc.) }\end{array}$ & \\
\hline & PU4 & $\begin{array}{l}\text { The use of the NFC mobile payment NFC will improve my decision } \\
\text { making process as a consumer (e.g. flexibility, speed, etc.). }\end{array}$ & \\
\hline \multirow{5}{*}{$\begin{array}{l}\text { Perceived ease of use } \\
\text { of NFC payment } \\
\text { systems }\end{array}$} & PEOU1 & It is easy to become skilful at using NFC mobile payment system & \multirow{5}{*}{$\begin{array}{l}\text { Bhattacherjee (2001), } \\
\text { Davis } \\
\text { et al. (1989), } \\
\text { Taylor and Todd (1995), } \\
\text { Venkatesh and Davis } \\
\text { (2000), Schierz et al. } \\
\text { (2010) }\end{array}$} \\
\hline & PEOU2 & $\begin{array}{l}\text { Interactions with NFC mobile payment system are clear and } \\
\text { understandable }\end{array}$ & \\
\hline & & & \\
\hline & PEOU3 & It is easy to follow all the steps to use NFC mobile payment system & \\
\hline & PEOU4 & It is easy to interact NFC mobile payment system & \\
\hline \multirow{4}{*}{$\begin{array}{l}\text { Perceived security of } \\
\text { NFC payment systems }\end{array}$} & PS1 & $\begin{array}{l}\text { The risk of an unauthorized party intervening in the payment process is } \\
\text { low (PS1) }\end{array}$ & \multirow{4}{*}{$\begin{array}{l}\text { Luarn and Lin (2005), } \\
\text { Parasuraman et al. } \\
\text { (2005), Schierz et al. } \\
\text { (2010) }\end{array}$} \\
\hline & PS2 & $\begin{array}{l}\text { The risk of abuse of usage information (e.g., names of business partners, } \\
\text { payment amount) is low when using NFC mobile payment system (PS2) }\end{array}$ & \\
\hline & PS3 & $\begin{array}{l}\text { The risk of abuse of billing information (e.g., credit card number, bank } \\
\text { account data) is low when using NFC mobile payment (PS3) }\end{array}$ & \\
\hline & PS4 & $\begin{array}{l}\text { I would like that the NFC payment system is safe for my financial } \\
\text { transactions. }\end{array}$ & \\
\hline \multirow{3}{*}{$\begin{array}{l}\text { Perceived } \\
\text { Compatibility in NFC } \\
\text { payment systems }\end{array}$} & PC1 & NFC mobile payment system use fits well in my lifestyle & \multirow{3}{*}{$\begin{array}{l}\text { Moore and Benbasat } \\
\text { (1991), } \\
\text { Plouffe et al. (2001), } \\
\text { Schierz et al. (2010) }\end{array}$} \\
\hline & PC2 & $\begin{array}{l}\text { NFC mobile payment use is consistent with the way I like to buy } \\
\text { products and services }\end{array}$ & \\
\hline & PC3 & $\begin{array}{l}\text { I would appreciate to use NFC payment system over other kinds } \\
\text { payment systems (for example, cash or traditional credit cards.) }\end{array}$ & \\
\hline \multirow{3}{*}{ Subjective Norms } & SN1 & $\begin{array}{l}\text { People who are important to me would recommend using NFC mobile } \\
\text { payment system }\end{array}$ & \multirow{3}{*}{$\begin{array}{l}\text { Taylor and Todd (1995), } \\
\text { Venkatesh and Davis } \\
(2000) \text {, Schierz et al. } \\
(2010)\end{array}$} \\
\hline & $\mathrm{SN} 2$ & $\begin{array}{l}\text { People who are important to me view NFC mobile payment system as } \\
\text { beneficial }\end{array}$ & \\
\hline & SN3 & $\begin{array}{l}\text { People who are important to me think it is a good idea to use NFC } \\
\text { mobile payment systems }\end{array}$ & \\
\hline \multirow{4}{*}{ Individual Mobility } & IM1 & I could imagine having multiple jobs at a time & \multirow{4}{*}{ Schierz et al. (2010) } \\
\hline & IM2 & I would like to be able to keep in touch everywhere I am & \\
\hline & IM3 & I would like to be able to coordinate my daily tasks everywhere I am & \\
\hline & IM4 & I would like to be able to coordinate my daily tasks anytime. & \\
\hline \multirow{4}{*}{$\begin{array}{l}\text { Personal } \\
\text { Innovativeness } \\
\text { in Information } \\
\text { Technology }\end{array}$} & PIIT1 & $\begin{array}{l}\text { If I find out about new information technology, I seek ways to } \\
\text { experience it }\end{array}$ & \multirow{4}{*}{$\begin{array}{l}\text { Agarwal and Prasad } \\
(1998), \\
\text { Lu et al. }(2005)\end{array}$} \\
\hline & PIIT2 & $\begin{array}{l}\text { I am usually one of the first among my colleagues/peers to explore new } \\
\text { information technology }\end{array}$ & \\
\hline & PIIT3 & In general, I am reluctant to try new information technologies* & \\
\hline & PIIT4 & I like to test new information technologies & \\
\hline
\end{tabular}

* The item uses inverse scale 
The method of data collection applied in this study was considered appropriate since it provided a quantitative description of attitudes, experiences and opinions of a sample of mobile users in Brazil without the influence of an interviewer or being put under pressure. It therefore has a greater guarantee of preserving anonymity and privacy, aspects that encourage more lucid and honest responses (Bowers, 1998; Viehland \& Leong, 2007).

\subsection{Data collection and the sample}

The population from which to draw conclusions was defined as all individuals capable of using mobile phones in Brazil. One reason for this choice is due to the fact that the current number of individuals who can carry out at least one NFC payment, besides being very small, is, a priori, very difficult to identify. In addition, it is of interest to identify the acceptance of the NFC at this early stage (when most people are unaware of how to properly apply it) so as to yield a better idea of their intention of use.

The procedure chosen for this research was that of a snowball sampling (also called referral sampling) using researcher social networks as it was not possible to obtain a list of individuals with the characteristics mentioned above. The process was initiated in Facebook through invitations sent by private message or posted on bulletin boards with a brief explanation of the study and providing the link to the research. In addition, participants were asked to forward the invitation to others of their network, as recommended by Aaker, Kumar and Day (2010).

A total of 610 forms were collected at the deadline of the questionnaire. After the elimination of incomplete forms, a final sample consisted of 423 individuals spread across the 26 States and the Federal District of Brazil. Table 2 lists the socio-demographic characteristics of the respondents.

Table 2

\section{Socio-demographic characteristics of the sampling}

\begin{tabular}{|c|c|c|c|c|c|}
\hline State & fi & $\%$ & Gender & fi & $\%$ \\
\hline Acre & 10 & 2.4 & Male & 235 & 55.6 \\
\hline Alagoas & 8 & 1.9 & Female & 188 & 44.4 \\
\hline Amapá & 8 & 1.9 & Total & 423 & 100 \\
\hline Amazonas & 14 & 3.3 & & & \\
\hline Bahía & 16 & 3.8 & Age range & fi & $\%$ \\
\hline Ceará & 10 & 2.4 & Less than 18 & 15 & 3.5 \\
\hline Distrito Federal & 11 & 2.6 & From 18 to 24 & 198 & 46.8 \\
\hline Espírito Santo & 7 & 1.7 & From 25 to 34 & 147 & 34.8 \\
\hline Goiás & 50 & 11.8 & From 35 to 44 & 28 & 6.6 \\
\hline Maranhão & 7 & 1.7 & From 45 to 54 & 23 & 5.4 \\
\hline Mato Grosso & 4 & 0.9 & More than 54 & 12 & 2.9 \\
\hline Mato Grosso do Sul & 9 & 2.1 & Total & 423 & 100 \\
\hline Minas Gerais & 11 & 2.6 & & & \\
\hline Paraíba & 108 & 25.5 & Primary and secondary school & 30 & 7.1 \\
\hline Pará & 2 & 0.5 & University & 277 & 65.5 \\
\hline Pernambuco & 7 & 1.7 & Post-graduate & 116 & 27.4 \\
\hline Piauí & 11 & 2.6 & Total & 423 & 100 \\
\hline Rio de Janeiro & 9 & 2.1 & & & \\
\hline Rio Grande do Norte & 18 & 4.3 & Knowledge of technology & fi & $\%$ \\
\hline Rio Grande do Sul & 9 & 2.1 & No knowledge & 148 & 35.0 \\
\hline Rondônia & 7 & I.7 & Heard of, but unaware of how it works & 109 & 25.8 \\
\hline Roraima & 1 & 0.2 & Heard of basically through the media & 140 & $33 . \mathrm{I}$ \\
\hline Santa Catarina & $2 I$ & 5.0 & Knows and used during a period of test. & 18 & 4.3 \\
\hline Sergipe & 3 & 0.7 & Knows and uses on an everyday basis & 8 & I.9 \\
\hline São Paulo & 42 & 9.9 & TOTAL & 423 & IOO \\
\hline
\end{tabular}


Before proceeding with the analysis of the data, and in the interest in the study, $6.2 \%$ of the sample was excluded as it comprised individuals already possessing NFC experience that would be biased.

\subsection{Data analysis technique}

The main technique used to prove the hypotheses formulated in this study was that of the Structural Equation Model using Amos 21 and SPSS 20 software from the IBM SPSS Statistics package.

\section{Data analysis and results}

The first step of the procedure was to evaluate the online form's variances $\left(R^{2}\right)$. Secondly, as recommended by the literature, items with variance of less than 0.5 were singled out and excluded (Martínez, 2012). These were: SP4 (0.06) of the construct "perceived security;" UP4 (0.45) of the construct "perceived usefulness;"
MI1 (0.21) of the construct "individual mobility;" PIIT2 (0.37) and PIIT3 (0.05) of the construct regarding "personal innovation."

\section{I Composite reliability and Variance Extracted}

To ensure that the variables that make up each factor were internally consistent, we tested the internal consistency with Cronbach's Alpha Test that revealed all values to be greater than 0.7 , the limit suggested by the literature (Nunnally, 1978). Furthermore, a Confirmatory Factor Analysis was carried out to establish the convergent and divergent validity of the scales.

The reliability of the scale can be evaluated from a series of indicators gleaned from the confirmatory analysis. Hence the values of the composite reliability (CR) and Average Variance Extracted (AVE) are in accordance to the requirements in the literature (Martínez, 2012) as at 0.7 and 0.5 respectively they exceed the reference threshold (Table 3 ).

Table 3

Analysis of the confidence and validity of the scales

\begin{tabular}{|c|c|c|c|c|c|}
\hline From & To & Standard Coefficient (SC) & Cronbach's Alpha & CR & AVE \\
\hline \multirow{3}{*}{ Perceived compatibility } & PC1 & 0.770 & \multirow{3}{*}{0.886} & \multirow{3}{*}{0.89} & \multirow{3}{*}{0.74} \\
\hline & PC2 & 0.903 & & & \\
\hline & PC3 & 0.898 & & & \\
\hline \multirow{3}{*}{ Perceived security } & PS1 & 0.847 & \multirow{3}{*}{0.917} & \multirow{3}{*}{0.92} & \multirow{3}{*}{0.79} \\
\hline & PS2 & 0.934 & & & \\
\hline & PS3 & 0.887 & & & \\
\hline \multirow{3}{*}{ Perceived usefulness } & PU1 & 0.819 & \multirow{3}{*}{0.846} & \multirow{3}{*}{0.84} & \multirow{3}{*}{0.64} \\
\hline & PU2 & 0.767 & & & \\
\hline & PU3 & 0.809 & & & \\
\hline \multirow{4}{*}{ Perceived ease of use } & PEOU1 & 0.756 & \multirow{4}{*}{0.915} & \multirow{4}{*}{0.92} & \multirow{4}{*}{0.74} \\
\hline & PEOU2 & 0.839 & & & \\
\hline & PEOU3 & 0.918 & & & \\
\hline & PEOU4 & 0.915 & & & \\
\hline \multirow{3}{*}{ Individual mobility } & IM2 & 0.783 & \multirow{3}{*}{0.887} & \multirow{3}{*}{0.89} & \multirow{3}{*}{0.74} \\
\hline & IM3 & 0.945 & & & \\
\hline & IM4 & 0.846 & & & \\
\hline \multirow{4}{*}{ Attitude toward the use } & ATU1 & 0.832 & \multirow{4}{*}{0.912} & \multirow{4}{*}{0.91} & \multirow{4}{*}{0.72} \\
\hline & ATU2 & 0.854 & & & \\
\hline & ATU3 & 0.866 & & & \\
\hline & ATU4 & 0.833 & & & \\
\hline \multirow{3}{*}{ Subjective norms } & SN1 & 0.866 & \multirow{3}{*}{0.938} & \multirow{3}{*}{0.94} & \multirow{3}{*}{0.84} \\
\hline & SN2 & 0.947 & & & \\
\hline & SN3 & 0.932 & & & \\
\hline \multirow{4}{*}{ Intention of use } & IU1 & 0.874 & \multirow{4}{*}{0.939} & \multirow{4}{*}{0.94} & \\
\hline & IU2 & 0.835 & & & 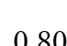 \\
\hline & IU3 & 0.940 & & & 0.00 \\
\hline & IU4 & 0.921 & & & \\
\hline & PIIT1 & 0.795 & & & \\
\hline Individual innovation in 11 & PIIT4 & 0.776 & 0.795 & 0.76 & 0.62 \\
\hline
\end{tabular}


With respect to the discriminant validity, it was shown that the variance was significantly different from zero and that the correlations between each pair of scales did not exceed 0.9, as recommended by various authors (Hair, Anderson, Tatham \& William, 1995; Martínez, 2012).

The analyses of the sample's asymmetry and kurtoses found that it does not follow a normal distribution (Mardia's coefficient = 401.15; CR =94.25). Therefore, following the recommendations of Hair et al. (1995), we carried out the most appropriate estimation procedure using the maximum robust likelihood method or bootstrap technique (2,000 replicates). In Bootstrap technique we use the p-value adjusted by the Bollen-Stine method, testing the null hypothesis to determine if the model is correct. This resampling technique corrects the construct's standard of error.

\section{$5 \cdot 2$ Structural model}

The structural model used in this study was verified through the structural model global adjustment goodness of fit indicators. These proved satisfactory as they had values acceptable according to those recommended by the literature (Bollen, 1989; Lai \& Li, 2005) both in absolute measures of adjustment as measured in the incremental adjustment model $\left(\mathrm{X}^{2}=767.228\right.$ $\mathrm{gl}=350 ;$ RMSEA $=0.055 ; \mathrm{RFI}=0.913$; $\mathrm{GFI}=$ 0.887 ; $\mathrm{AGFI}=0.859 ; \mathrm{NFI}=0.925 ; \mathrm{CFI}=0.958$; $\mathrm{IFI}=0.958)$.

The GFI index, in turn, is a very sensitive index that can vary according to the conditions of the sample. For this reason, it has become less popular in recent years. When there is a large degree of freedom in relation to the size of the sample, the GFI shows a downward skewing (Sharma, Mukherjee, Kumar, \& Dillon, 2005). Therefore, although the GFI index did not meet the recommended minimum values, the discrepancy represented by the amount of 0.013 lead us to believe that the adjustment model was reasonably adequate to evaluate the result to the structural model.

\subsection{Hypothesis Test}

The testing of the hypotheses reveals that the ratios of the significant trajectories appear to support the model, in spite that not all relations obtained empirical support. Figure 1 and Table 4 briefly summarize the results of the hypotheses testing.

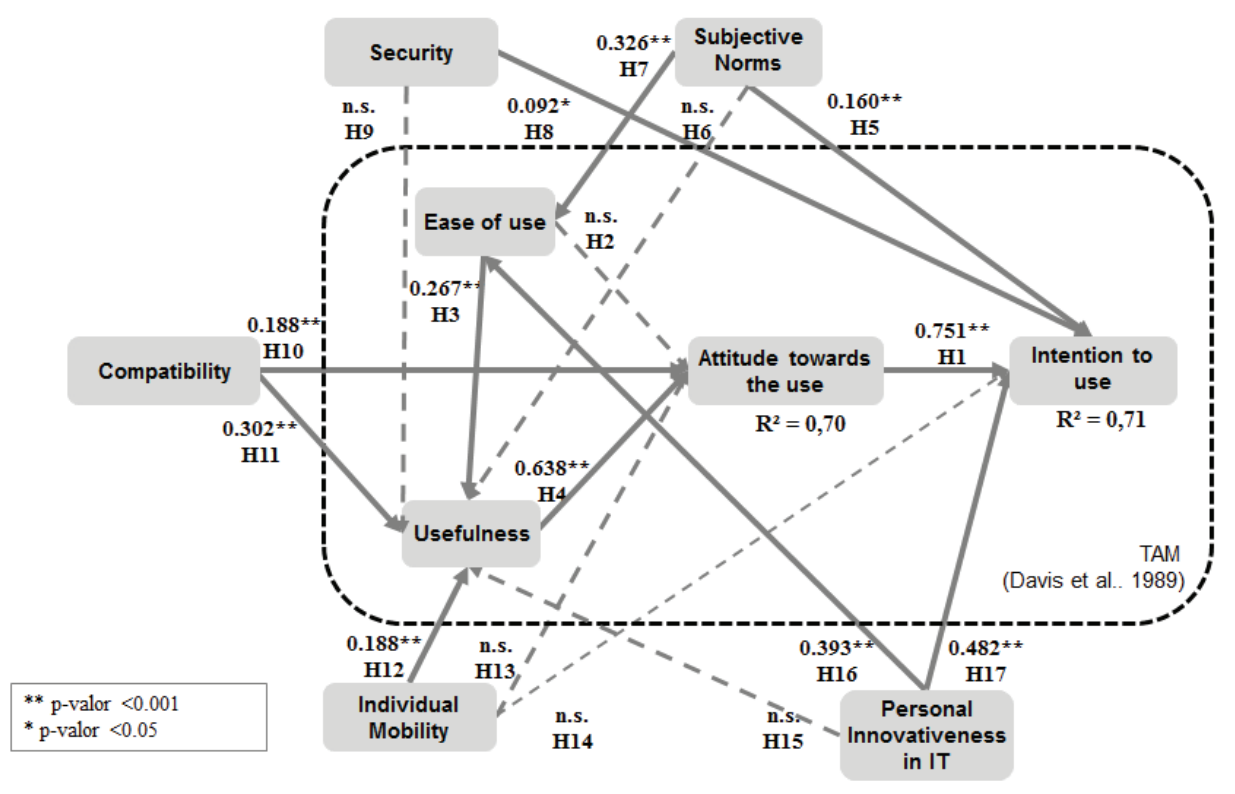

Figure 1. Final model of NFC mobile payment system acceptance 
Table 4

Hypotheses test

\begin{tabular}{|c|c|c|c|c|c|c|}
\hline Variable & & & Hypothesis & Estimation & P-value & Result \\
\hline Attitude toward the use (ATU) & $\rightarrow$ & IU & $\mathrm{H} 1$ & 0.736 & $<0.001$ & Supported \\
\hline \multirow{2}{*}{ Perceived Ease of Use (PEOU) } & \multirow{2}{*}{$\rightarrow$} & ATU & $\mathrm{H}_{2}$ & 0.073 & $0.14 \mathrm{I}$ & Rejected \\
\hline & & PU & $\mathrm{H}_{3}$ & 0.286 & $<0.00 \mathrm{I}$ & Supported \\
\hline Perceived Usefulness (PU) & $\rightarrow$ & ATU & $\mathrm{H}_{4}$ & 0.584 & $<0.001$ & Supported \\
\hline \multirow{3}{*}{ Subjective norms (SN) } & \multirow{3}{*}{$\rightarrow$} & IU & $\mathrm{H}_{5}$ & 0.156 & $\leq 0.00 \mathrm{I}$ & Supported \\
\hline & & PU & H6 & 0.037 & 0.372 & Rejected \\
\hline & & PEOU & $\mathrm{H}_{7}$ & $0.3 \mathrm{I} 3$ & $<0.001$ & Supported \\
\hline \multirow{2}{*}{ Perceived Security (PS) } & \multirow{2}{*}{$\rightarrow$} & IU & $\mathrm{H} 8$ & 0.087 & $0.02 \mathrm{I}$ & Supported \\
\hline & & PU & $\mathrm{H}_{9}$ & -0.016 & 0.604 & Rejected \\
\hline \multirow{2}{*}{ Perceived Compatibility (PC) } & \multirow{2}{*}{$\rightarrow$} & ATU & Hio & 0.189 & $<0.001$ & Supported \\
\hline & & PU & HII & 0.284 & $<0.001$ & Supported \\
\hline \multirow{3}{*}{ Individual Mobility (IM) } & \multirow{3}{*}{$\rightarrow$} & PU & $\mathrm{H}_{2} 2$ & 0.162 & 0.002 & Supported \\
\hline & & ATU & $\mathrm{H}_{13}$ & 0.045 & $0.32 \mathrm{I}$ & Rejected \\
\hline & & IU & $\mathrm{H}_{4} 4$ & -0.130 & $0.05 \mathrm{I}$ & Rejected \\
\hline \multirow{3}{*}{ Personal Innovativeness in IT (PIIT) } & \multirow{3}{*}{$\rightarrow$} & PU & His & -0.063 & $0.4 \mathrm{I} 2$ & Rejected \\
\hline & & PEOU & Hi 6 & 0.393 & $<0.00 \mathrm{I}$ & Supported \\
\hline & & IU & $\mathrm{H}_{77}$ & 0.503 & $<0.00 \mathrm{I}$ & Supported \\
\hline
\end{tabular}

The values allow us to determine that the attitude to the use of NFC payment in Brazil positively determines the intention of use ( $\beta=0.736, p<0.001)$ supporting hypothesis 1 (H1). This confirms the results of previous studies on the acceptance of technology (Lu et al., 2003; Chen \& Adams, 2005; Bigné-Alcañiz et al., 2008; Kim et al., 2010; Yang et al., 2012).

The relationship between perceived ease of use and the attitude to use did not receive empirical support which allows us to state that perceived ease of use of NFC technology does not positively determine the attitude to use as proposed in $\mathrm{H} 2(\beta=0.073 ; \mathrm{p}=0.141)$. The perception of ease of use, in turn, positively determines the perception of the usefulness of the technology $(\beta=0.286, \mathrm{p}<0.001)$ as proposed in $\mathrm{H} 3$.
Although the results exclude the possibility that the ease of use positively determines the attitude of use (H2) and refute the results advocated by Davis et al. (1989) in the Technology Acceptance Model (TAM), H4 does have empirical support that allows us to state that the perceived usefulness positively determines the attitude of use of NFC ( $\beta=0.584, \mathrm{p}<0.001)$, bolstering the TAM proposition by Davis (1989).

With regard to subjective standards, the findings show that they positively determine both the intention to use NFC as proposed in $\mathrm{H} 5$ $(\beta=0.156, p \leq 0.001)$ and as in the case of ease of use as proposed in H7 ( $\beta=0.313, \mathrm{p}<0.001)$. Yet it does not support Hypothesis $6(\beta=0.037$, $\mathrm{p}=0.372$ ) suggesting that subjective norms do not positively determine the perceived usefulness of this technology. 
The relationship proposed by $\mathrm{H} 8$ between the perception of security of the NFC and the intention to use it was supported ( $\beta=0.087$; $\mathrm{p}=0.021)$ as suggested by Grassie (2007). Meanwhile the idea proposed in $\mathrm{H} 9$ that perceived security would positively affect the perceived utility did not receive empirical support $(\beta=-0.016$, $\mathrm{p}=0.604)$. Hence, the perception of security does not influence the perceived usefulness of the payment system in question.

The compatibility perceived by future users proved to be a relevant factor for the acceptance of the NFC payment system as the results show that this factor has a positive effect on both the attitude to use $(\beta=0.189, \mathrm{p}<0.001)$ and the perceived usefulness $(\beta=0.284, \mathrm{p}<0.001)$. These relations are also respectively proposed in Hypotheses 10 and 11.

Hypothesis 12, which states that individual mobility positively determines the value perceived by the individual, obtained empirical support $(\beta=0.162 ; p=0.002)$. Yet H14, that states that such mobility positively determines the intended use of the NFC, did not receive empirical support ( $\beta=-0.130, p=0.051)$. Neither did H13 stating that individual mobility determines the attitude to use of NFC payments $(\beta=0.045 ; \mathrm{p}=0.321)$.

The findings do not show that personal innovation in IT (PIIT) determines the perception of utility of the future user $(\beta=-0.063 ; \mathrm{p}=0.412)$ as advanced in $\mathrm{H} 15$, but positively determines the perceived ease of use $(\beta=0.393 ; \mathrm{p}<0.001)$ proposed in $\mathrm{H} 16$, as well as the intention to use the NFC payment system in the short term $(\beta=0.503, \mathrm{p}<0.001)$ proposed in H17. This shows that this is also a factor that directly influences the intention to use and is of great importance to the introduction of this new payment tool on the market.

\section{Conclusions}

This study analyzes the acceptance by consumers of the NFC mobile payment system. This is carried out from a behavioral model that includes determining factors for the acceptance of technology of which the main factor of acceptance is the intention of use. In this sense the model proposed in this paper for NFC payment use has a predictive power of $71 \%$ which shows that it includes earlier items with a great predictive power of NFC acceptance since its values are those of other models of acceptance of similar technologies (Lu et al., 2011; Lu et al., 2005; Yang et al., 2012).

As to future use of NFC technology for payments, we found that the variables with the greatest influence on the intention to use were the Attitude to use at 74\%, Personal Innovation in IT at 56\% followed by Perceived Usefulness at $43 \%$. Attitude has a significant positive and direct effect on intention to use. The power of attitude is notorious probably because users facing new technologies usually demonstrate curiosity and are predisposed to their acceptance.

The last two aspects mentioned above are relevant because new technologies, especially those linked to the customer's finances, will be adopted in principle by individuals who are open to new technologies and technological change, and therefore more adapted to accept them. Furthermore, if an innovation is also viewed as useful, its adoption will be easier. In the case of NFC payment, the combination of Personal Innovation and Perceived Usefulness by the future user is proven to be a winning combination for the adoption in Brazil at the moment of its introduction.

Despite having a smaller effect on the intention of use, perceived compatibility and subjective standards are also important factors in the adoption of the NFC payment system as they have an influence of $26 \%$ and $23 \%$, respectively, on the intention of use. It is essential for this type of technology, especially in the phase of introduction to the market, to be compatible with people's lives and that people recognize this compatibility. Subjective norms, in turn, are reflected in the current high interconnection between individuals stemming from both the rapid development of mobile communication technologies and the widespread use of virtual 
social networks. This implies that users take into account the opinions of others important to them.

Finally, the perceived ease of use also has a significant effect (18\%) on intention to use and, to a lesser extent, on perceived security (8\%). In fact, the notion of security is seldom considered among studies of the acceptance of mobile technologies. In the current study it resulted relevant mainly because it is a financial tool of users with a greater perceived level of security who have a greater propensity to accept new contactless mobile payment systems.

The relationship between individual mobility and intention of use revealed a small but significant negative value $(-2.7 \%)$. This is probably the result of the high degree of mobility of the sampled population and that the intention of use of the tool does not depend on this factor, but rather on attitude, personal innovation and perceived usefulness. Furthermore, since the expense of mobile phones in Brazil is very high, users are accustomed to the use of mobile technologies and initially do not value this advantage.

\section{I Academic contributions and future lines of research}

Although several studies on the acceptance of mobile payments and mobile technology have been published, the current paper is one of the first empirical works on the determinants of acceptance of the NFC payment system from a Brazilian perspective. Besides the general thoughts laid out in the preceding paragraphs, it is our hope that the current research will serve as a starting point, in particular in Brazil, for future empirical and conceptual studies on the acceptance of NFC technology or on other contactless mobile payment systems and technologies.

We propose that future research in Brazil also include other variables that are essential to the process of adopting new technologies such as the experience with credit card payments or other mobile payment systems. We also encourage other researchers to use a more representative sample so as to draw a profile of the Brazilian population regarding the intention to use of this type of payment technology.

Taking into account that growth in the use of NFC technology throughout the world is a reality and that our study is limited to a Brazilian sample, it would be interesting to compare the conceptual model of the current research with a sample from other specific countries or regions, so as to explore the effects of cultural differences in the process of adoption of the NFC payment system.

\subsection{Implications for professionals and businesses}

The results of this exclusively Brazilian sample are of interest to businesses and other stakeholders in the Brazilian market that aim to promote NFC technology or payment by mobile phone using Brazilian technology. Companies that develop solutions for electronic payment, as well as businesses aiming to expand ways for customers to pay for goods and services, can draw valuable information from this work to expand adoption of contactless mobile payment systems, in particular those equipped with NFC technology.

Although the key, in our opinion, to the adoption of such an innovative means of payment resides in a change of mentality, specifically a change from the practice of credit card and cash use to mobile phone payment. It is important to bear in mind that mobile payments require a complex web of relationships between a wide number of actors to offer financial services to a underprivileged part of the population, which is at the same time supported by a strong government regulation (Diniz, De Albuquerque \& Cernev, 2011).

The actors interested in popularizing NFC payment in Brazil must do their part while heeding to other, less significant, factors that are, nonetheless, central to the process of adoption of payment with mobiles. This is the case of the factors of ease of use and security, or 
even, as suggested by Dahlberg et al., (2008), of the very elements of the current technological environment.

We believe, considering the current state of the NFC payment market in Brazil, that it is advisable that companies should first be alerted to the assessments of future use of NFC payment by consumers. The current study indicates that these initial assessments are positive and affect directly the intention to use, which will lead to use in the short term.

Focusing on users that are more familiar with new technologies and instruct them on the great utility of the NFC payment system is also an important piece of advice for those interested in encouraging the adoption of this tool. Users who enjoy testing new technologies can be a great means of spreading this system in the market. Revealing the utility of this payment tool should take on a role equal to that of incentives for its use.

It is important to emphasize that what is critical to the success of adoption of mobile contactless payments, especially those using technologies like NFC, is the use of marketing tools to create strategic campaigns aimed to educate users on the utility of this type of payment. The campaigns should also focus on demonstrating how the new system is compatible with their lives. It should also make clear that the tool is safe for financial transactions by displaying the security measures that include security seals or even links with renowned brands of financial security such as, for example, Visa or PayPal.

On the other hand, the effects of subjective norms on the intention of use also cannot be discarded. This work advances that businesses should seek to draw the most out of both virtual and real social networks to encourage information and thereby seek to promote all the benefits of this electronic means of payment.

\section{References}

Aaker, D. A., Kumar, V., \& Day, G. S. (2010). Pesquisa de marketing (2a ed.). São Paulo: Atlas.

Accenture (2015). North America consumer digital payments survey, press release, 2015.
Recuperado de https://www.accenture.com/ t20151021T165757__w__/us-en/_acnmedia/ Accenture/next-gen/na-payment-survey/pdfs/ Accenture-Digital-Payments-Survey-NorthAmerica-Accenture-Executive-Summary.pdf

Agarwal, R., \& Karahanna, E. (2000). Time flies when you're having fun: Cognitive absorption and beliefs about information technology usage. MIS Quarterly, 24(4), 665-694.

Agarwal, R., \& Prasad, J. (1998). A conceptual and operational definition of personal innovativeness in the domain of information technology. Information Systems Research, 9(2), 204-215.

Agência Nacional de Telecomunicações (Brasil). (2016). Brasil fecha abril de 2016 com 256,43 milhóes de acessos. Recuperado de http://www. anatel.gov.br/dados/index.php/destaque-1/283movel-acessos-maio

Ajzen, I. (1991). The theory of planned behavior. Organizational Behaviour and Human Decision Processes, 50(2), 179-211.

Bhattacherjee, A. (2001). An empirical analysis of the antecedents of electronic commerce service continuance. Decision Support Systems, 32(2), 201-214.

Bhatti, T. (2007). Exploring factors influencing the adoption of mobile commerce. Journal of Internet Banking and Commerce, 12(3), 1-13.

Bigné-Alcañiz, E., Ruiz-Mafé, C., AldásManzano, J., \& Sanz-Blas, S. (2008). Influence of online shopping information dependency and innovativeness on internet shopping adoption. Online Information Review, 32(5), 648-667.

Bollen, K. A. (1989). Structural Equations with Latent Variables. Toronto: Wiley.

Bourreau, M., \& Verdier, M. (2010). Cooperation for innovation in payment systems: the case of mobile payments [Telecom ParisTech Working 
Paper No. ESS-10-02]. Department of Economics and Social Sciences TELECOM, Paris, France. Recuperado de http://ssrn.com/abstract $=1575036$

Bowers, D. K. (1998). FAQs on online research. Marketing Research, 10(4), 45-48.

Badra, M., \& Badra, R. B. (2016). A lightweight security protocol for $\mathrm{nfc}$-based mobile payments. Procedia Computer Science, 83, 705-711.

Central Intelligence Agency. (2016). The World FactBook: Country comparison - telephones mobile cellular, 2016. Recuperado de https:// www.cia.gov/library/publications/the-worldfactbook/rankorder/2151 rank.html

Chau, P. Y. K., \& Lai, V. S. K. (2003). An empirical investigation of the determinants of user acceptance of internet banking. Journal of Organizational Computing and Electronic Commerce, 13(2), 123-145.

Chen, J. J., \& Adams, C. (2005). User acceptance of mobile payments: A theoretical model for mobile payments. Proceedings of the International Conference on Electronic Business, Hong Kong, China, 5.

Cho, J. (2004). Likelihood to abort an online transaction: Influences from cognitive evaluations, attitudes, and behavioral variables. Information \& Management, 41(7), 827-838.

Chung, J. E., Stoel, L., Xu, Y., \& Ren, J. (2012). Predicting Chinese consumers' purchase intentions for imported soy-based dietary supplements. British Food Journal, 114(1), 143-161.

Dahlberg, T., Guo, J., \& Ondrus, J. (2015). A critical review of mobile payment research. Electronic Commerce Research and Applications, 14(5), 265-284.

Dahlberg, T., Mallat, N., \& Oorni, A. (2003, May). A trust enhanced technology acceptance model: Consumer acceptance of mobile payment solutions. Proceedings of the Stockholm Mobility Rountdtable, Stockholm.

Davis, F. D. (1989). Perceived usefulness, perceived ease of use, and user acceptance of information technology. MIS Quarterly, 13(3), 319-340.

Davis, F. D., Bagozzi, R. P., \& Warshaw, P. R. (1989). User acceptance of computer technology: A comparison of two theoretical models. Management Science, 35(8), 982-1003.

Diniz, E. H., De Albuquerque, J. P., \& Cernev, A. K. (2011). Mobile money and payment: A literature review based on academic and practitioner-oriented publications (2001-2011). Proceedings of SIG Global Development Annual Workshop, Shanghai, China, 4.

Devaraj, S., Fan, M., \& Kohli, R. (2002) Antecedents of B2C channel satisfaction and preference, Validating e-commerce metrics. Information Systems Research, 13(3), 316-333.

Duncombe, R., \& Boateng, R. (2009). Mobile phones and financial services in developing countries: A review of concepts, methods, issues, evidence and future research directions. Third World Quarterly, 30(7), 1237-1258.

Emarketer. (2015). Smartphones still for browsing more than buying. Recuperado de http:// www.emarketer.com/Article/Smartphones-StillBrowsing-More-than-Buying/1013065

Ericsson. (2016). Ericsson mobility report: On the pulse of the networked society. Recuperado de https://www.ericsson.com/res/docs/2016/ ericsson-mobility-report-2016.pdf

First Annapolis. (2016). Apple Pay Awareness, Adoption Plateau According to First Annapolis Survey. Recuperado de http://www.firstannapolis. com/news/apple-pay-awareness-adoptionplateau-according-to-first-annapolis-survey 
Fishbein, M., \& Ajzen, I. (1975). Belief, attitude, intention and behavior: An introduction to theory and research, Reading, MA: Addison-Wesley.

Gefen, D., Karahanna E., \& Straub, D.W. (2003). Trust y TAM in online shopping: An integrated Model. MIS Quarterly, 27(1), 51-90.

Glass, R., \& Li, S. (2010). Social influence and instant messaging adoption. Journal of Computer Information Systems, 51(2), 24-30.

Grassie, K. (2007). Easy handling and security make NFC a success. Card Technology Today, 19(10), 12-13.

GSMA Association. (2012). Brazil mobile observatory 2012. Recuperado de http://www. gsma.com/publicpolicy/public-policy-resources/ mobile-observatory-series

GSMA Intelligence. (2016). $4 G$ connections in Brazil to reach 42 million in 2016. Recuperado de http://www.gsma.com/latinamerica/4gconnections-in-brazil-to-reach-42-millionin-2016

Google. (2012). Nosso planeta mobile: Brasil. Como entender o usuário de celular. Recuperado de http://services.google.com/fh/files/blogs/ our_mobile_planet_brazil_pt_BR.pdf.

Groß, M. (2015). Mobile shopping: A classification framework and literature review, International Journal of Retail \& Distribution Management, 43(3), 221-241.

Hair, J. F., Anderson, R. E., Tatham, R. L., \& William, C. B. (1995). Multivariate data analysis with readings. New Jersey: Prentice-Hall, Inc.

Herrero Crespo, A., García de Los Salmones, M. M., \& Rodríguez Del Bosque, I. A. (2005, septiembre 21-23). La propensión a innovar en la adopción del comercio electrónico B2C: Un análisis obre la base de la teoría de acción razonada. Actas Encuentro de Profesores Universitarios de Marketing, Madrid, 17.
Hernández, J. (2010). Análisis y modelización del comportamiento de uso de las herramientas Travel 2.0 (Tese de Doutorado). Departamento de Comercialización e Investigación de Mercados. Universidad de Granada, Granada, Espanha.

Kang, J. Y. M., Mun, J. M., \& Johnson, K. K. P. (2015). In-store mobile usage: downloading and usage intention toward mobile location-based retail apps. Computers in Human Behavior, 46, 210-217.

Kerviler, G., Demoulin, N. T. M., \& Zidda, P. (2016). Adoption of in-store mobile payment: Are perceived risk and convenience the only drivers? Journal of Retailing and Consumer Services, 31, 334-344.

Kim, C., Mirusmonov, M., \& Lee, I. (2010). An empirical examination of factors influencing the intention to use mobile payment. Computers in Human Behavior, 26(3), 310-322.

Kleinrock, L. (1997). Nomadicity: Anytime, anywhere in a disconnected world. Mobile Networks and Applications, 1(4), 351-357.

Lai, J. Y., \& Li, D. H. (2005). Technology acceptance model for internet banking: An invariante analysis. Information \& Management, 42(2), 373-386.

Leong, L.Y., Hew, T. S., Tan, G. W. H., \& Ooi, K. B. (2013). Predicting the determinants of the NFC-enabled mobile credit card acceptance: A neural networks approach. Expert Systems With Applications, 40(14), 5604-5620.

Lewis, W., Agarwal, R., \& Sambamurthy, V. (2003). Sources of influence on beliefs about information technology use: An empirical study of knowledge workers. MIS Quarterly, 27(4), 657-679.

Liébana-Cabanillas, F., Muñoz-Leiva, F., IbáñezZapata, J. A., \& Rey-Pino, J. (2012). The role of mobile payment systems in Electronic Commerce. Actas de la EMAC Conference, Lisboa, Mayo, 41. 
Liébana-Cabanillas, F., Ramos-De-Luna, I., \& Montoro-Ríos, F. J. (2015). User behaviour in $\mathrm{QR}$ mobile payment system: the QR Payment Acceptance Model. Technology Analysis \& Strategic Management, 27(9), 1031-1049.

Lu, Y., Yang, S., Chau, P., \& Cao, Y. (2011). Dynamics between the trust transfer process and intention to use mobile payment services: A cross-environment perspective. Information \& Management, 48(8), 393-403.

Lu, J., Yao, J., \& Ye, C. S. (2005). Personal innovativeness, social influences and adoption of wireless internet services via mobile technology. The Journal of Strategic Information Systems, 14(3), 245-268.

Lu, J., Yu, C., Liu, C., \& Yao, J. E. (2003). Technology acceptance model for wireless internet. Internet Research, 13(3), 206-222.

Luarn, P., \& Lin, H.H. (2005). Toward an understanding of the behavioral intention to use mobile banking. Computer in Human Behavior, 21(6), 873-891.

Luna, I. R. (2012.) Un estudio empirico de la aceptación de la tecnología NFC para pago móvil en España (Dissertação de mestrado). Departamento de Comercialización e Investigación de Mercados. Universidad de Granada, Espanha.

Luna, I. R., Montoro-Ríos, F. J., \& LiébanaCabanillas, F. (2016). Determinants of the intention to use NFC technology as a payment system: an acceptance model approach. Information Systems and e-Business Management, 4(2), 293-314.

Madureira, A. (2017). Factors that hinder the success of SIM-based mobile NFC service deployments. Telematics and Informatics, 34(1),133-150.

Malhotra, Y., \& Galletta, D. F. (1999). Extending the technology acceptance model to account for social influence: Theoretical bases and empirical validation. Proceedings of the Annual Hawaii International Conference on System Sciences, 10061020, 32 .

Martínez, T. L. (2012). Técnicas de análisis de datos en investigación de mercados. Madrid, Espanha: Ediciones Pirámide.

Meharia, P. (2012). Assurance on the reliability of mobile payment system and its effects on its' use: An empirical examination. Accounting \& Management Information Systems / Contabilitate Si Informatica De Gestiune, 11(1), 97-111.

Moore, G. C., \& Benbasat, I. (1991). Development of an instrument to measure the perceptions of adopting an information technology innovation. Information Systems Research, 2(3), 173-191.

Morosan, C., \& Defranco, A. (2016). It's about time: Revisiting UTAUT2 to examine consumers' intentions to use NFC mobile payments in hotels. International Journal of Hospitality Management, 53, 17-29.

Muñoz, F. L., Hernández-Méndez, J., \& SánchezFernández, J. (2012). Generalising user behaviour in online travel sites through the travel 2.0 website acceptance model. Online Information Review, 36(6), 879-902.

Nunnally, J. C. (1978). Psychometric theory (2nd ed.). New York: McGraw-Hill.

Oh, S., Ahn, J., \& Kim, B. (2003). Adoption of broadband Internet in Korea: the role of experience in building attitudes. Journal of Information Technology, 18(4), 267-280.

Oliveira, T., Thomas, M., Baptista, G., \& Campos, F. (2016). Mobile payment: Understanding the determinants of customer adoption and intention to recommend the technology. Computers in Human Behavior, 61, 404-414.

Ondrus, J., \& Pigneur, Y. (2007). An assessment of NFC for future mobile payment systems. 
International Conference on the Management of Mobile Business - ICMB, Toronto, Canadá, 6.

Parasuraman, A., Zeithaml, V. A., \& Malhotra, A. (2005). E-S-QUAL: a multiple-item scale for assessing electronic service quality. Journal of Service Research, 7(3), 213-233.

Pham, T. T. T., \& Ho, J. C. (2015). The effects of product-related, personal-related factors and attractiveness of alternatives on consumer adoption of NFC-based mobile payments. Technology in Society, 43,159-172.

Plouffe, C. R., Hulland, J. \& Vandenbosch, M. (2001). Research Report: Richness Versus Parsimony in Modeling Technology Adoption Decisions -Understanding Merchant Adoption of a Smart Card-Based Payment System. Information Systems Research, 12(2), 208-222.

Rogers, E. M. (2003). Diffusion of Innovations (5th ed). New York: Free Press.

Sciarretta, T. (2016). Pagamentos mais inteligentes. Revista Ciab FEBRABAN, (62), 8-16. Recuperado de https://issuu.com/revistaciab/docs/revista_ ciab_62_abr16/8

Schierz, P. G., Schilke, O., \& Wirtz, B.W. (2010). Understanding consumer acceptance of mobile payment services: An empirical analysis. Electronic Commerce Research and Applications, 9(3), 209-216.

Sharma, S., Mukherjee, S., Kumar, A., \& Dillon, W. R. (2005). A simulation study to investigate the use of cutoff values for assessing model fit in covariance structure models. Journal of Business Research, 58(1), 935-43.

Shih, Y., \& Fang, K. (2004). The use of a decomposed theory of planned behavior to study internet banking in Taiwan. Internet Research: Electronic Networking Applications and Policy, 14(3), 213-223.
Shin, D. H. (2009). Towards an understanding of the consumer acceptance of mobile wallet. Computer in Human Behavior, 25(6), 1343-1354.

Simpson, J. (2015). NFC technology in packaging: Does it have a future? Recuperado de https:// econsultancy.com/blog/66690-nfc-technologyin-packaging-does-it-have-a-future/

Slade, E. L., Williams, M. D., \& Dwivedi, Y. K. (2013). Extending UTAUT2 to explore consumer adoption of mobile payments. Proceedings of the Uk Academy for Information Systems Conference, Oxford.

Slade, E., Williams, M., Dwivedi, Y., \& Piercy, N. (2014). Exploring consumer adoption of proximity mobile payments. Journal of Strategic Marketing, 23(3), 209-223.

Smart Card Alliance. (2011). The mobile payments and NFC landscape: A U.S. Perspective [Publication Number: PC-1 1002]. Recuperado de http://www. smartcardalliance.org/resources/pdf/Mobile_ Payments_White_Paper_091611.pdf

Statista. (2015). Total revenue of global mobile payment market from 2015 to 2019 (in billion U.S. dollars). Recuperado de http://www. statista.com/statistics/226530/mobile-paymenttransaction-volume-forecast/

Taylor, S., \& Todd, P. A. (1995). Understanding information technology usage: A test of competing models. Information Systems Research, 6(2), 144176.

Teo, A. C., Tan, G. W. H., Ooi, K. B., Hew, T. S., \& Yew, K. T. (2015). The effects of convenience and speed in m-payment. Industrial Management \& Data Systems, 115(2), 311-331.

Thatcher, J. B., \& Perrewe, P. L. (2002). An empirical examination of individual traits as antecedents to computer anxiety and computer self-efficacy. MIS Quarterly, 26(4), 381-397. 
Tornatzky, L. G., \& Klein, K. J. (1982). Innovation characteristics and innovation adoption-implementation: A meta-analysis of findings. IEEE Transactions on Engineering Management, 29(1), 28-43.

Van Der Heijden, H. (2003). Factors influencing the usage of websites: The case of a generic portal in The Netherlands. Information \& Management, $40(6), 541-549$.

Venkatesh, V., \& Bala, H. (2008). Technology acceptance model 3 and a research agenda on interventions. Decision Sciences, 39(2), 273-315.

Venkatesh, V., \& Davis, F. D. (2000). A theoretical extension of the technology acceptance model: Four longitudinal field studies. Management Science, 46(2), 186-204.

Viehland, D., \& Leong, R. S. Y. (2007, December). Acceptance and use of mobile payments. Proceedings of the Australasian Conference on
Information Systems, Toowoomba, 665-671, 18.

Zhang, A., Yue, X., \& Kong, Y. (2011). Exploring culture factors affecting the adoption of mobile payment. Proceedings of the International Conference on Mobile Business, 263-267, 10.

Yang, H.D., \& Yoo, Y. (2004). It's all about attitude: revisiting the technology acceptance model. Decision Support Systems, 38(1), 19-31.

Yang, S., Lu, Y., Gupta, S., Caso, Y., \& Zhang, R. (2012). Mobile payment services adoption across time: An empirical study of the effects of behavioral beliefs, social influences, and personal traits. Computers in Human Behavior, 28(1), 129-142.

Yusta, A. I., Ruiz, M. P. M., \& Zarco, A. I. J. (2010). Condicionantes económicos de la adopción de una innovación por parte del consumidor: análisis de la compra de servicios online. Innovar, 20(36), 173-186.

\section{Supporting Agencies:}

CAPES Fundation - Ministry of Education of Brazil. Cx postal 250, Brasilia, DF 70 040-020, Brazil

\section{Authors:}

1. Iviane Ramos de Luna, Master in Marketing and Consumer Behaviour, University of Granada, Spain.

E-mail: iviane@correo.ugr.es

2. Francisco J. Montoro-Ríos, Phd in Business and Economics Sciences, University of Granada, Spain.

E-mail: fmontoro@ugr.es

3. Francisco Liébana-Cabanillas, Phd in Business and Economics Sciences, University of Granada, Spain. E-mail: franlieb@ugr.es

4. Joáo Gil de Luna, Phd in Statistics and Agronomic Experimentation, Univertity of Sao Paulo, Brazil. E-mail: jgluna@cct.uepb.edu.br

\section{Contribution of each author:}

\begin{tabular}{|c|c|c|c|c|}
\hline Contribution & $\begin{array}{l}\text { Iviane Ramos } \\
\text { de Luna }\end{array}$ & $\begin{array}{l}\text { Francisco J. } \\
\text { Montoro-Ríos }\end{array}$ & $\begin{array}{l}\text { Francisco Liébana- } \\
\text { Cabanillas }\end{array}$ & Joáo Gil de Luna \\
\hline 1. Definition of research problem & $\sqrt{ }$ & $\sqrt{ }$ & $\sqrt{ }$ & \\
\hline $\begin{array}{l}\text { 2. Development of hypotheses or research questions } \\
\text { (empirical studies) }\end{array}$ & $\sqrt{ }$ & $\sqrt{ }$ & $\sqrt{ }$ & \\
\hline \multicolumn{5}{|l|}{$\begin{array}{l}\text { 3. Development of theoretical propositions } \\
\text { (theoretical Work) }\end{array}$} \\
\hline 4. Theoretical foundation/ Literature review & $\sqrt{ }$ & $\sqrt{ }$ & $\sqrt{ }$ & \\
\hline 5. Definition of methodological procedures & $\sqrt{ }$ & & & $\sqrt{ }$ \\
\hline 6. Data collection & $\sqrt{ }$ & & & $\sqrt{ }$ \\
\hline 7. Statistical analysis & $\sqrt{ }$ & & & \\
\hline 8. Analysis and interpretation of data & $\sqrt{ }$ & $\sqrt{ }$ & $\sqrt{ }$ & $\sqrt{ }$ \\
\hline 9. Critical revision of the manuscript & & $\sqrt{ }$ & $\sqrt{ }$ & $\sqrt{ }$ \\
\hline 10. Manuscript Writing & $\sqrt{ }$ & $\sqrt{ }$ & $\sqrt{ }$ & $\sqrt{ }$ \\
\hline
\end{tabular}

